\title{
EVALUACIÓN DE LA FACTIBILIDAD FINANCIERA DE LA INSTALACIÓN DE RED ANTIPÁJARO EN UN CULTIVO DE MANZANO (Malus domestica), EN LA ZONA CENTRAL DE LA PROVINCIA DE SANTA FE (ARGENTINA)
}

\author{
Scotta, R. ${ }^{1} ;$ Travadelo, M. ${ }^{2}$; Maina, M. ${ }^{2}$; Rossler, N. ${ }^{2}$ \& LUtZ, A. $^{1}$
}

\begin{abstract}
RESUMEN
La producción de frutales en el centro de Santa Fe sufre importantes pérdidas causadas por aves. El daño se puede controlar mediante redes antipájaros que ofrecen efectiva protección. El objetivo de este trabajo fue evaluar las pérdidas producidas por aves y la factibilidad financiera de la instalación de una red antipájaro sobre un cultivo de manzano. Se aplicó la técnica de formulación y evaluación de proyectos, para la instalación de la red antipájaros en manzano en el CECIFFCA-UNL. La inversión evaluada a 7 años, fue de 41.042 \$/ha, arrojó un VAN de 8.765 \$/ha, un periodo de repago de 4 años y una TIR de $16,17 \%$, siendo la relación B/C de 1,23. Se determinó como umbral una pérdida de producción de $25 \%$ a partir de la cual es conveniente realizar la inversión. Se concluye que la inversión es viable particularmente con niveles de daños altos. Palabras claves: Daño por aves; Red antipájaro; Manzano.
\end{abstract}

\section{SUMMARY}

\section{Evaluation of the financial viability of installing exclusion netting in apple (Malus domestica), in Santa Fe (Argentina).}

Fruit production in Santa Fe area suffers important losses caused by birds. The damage can be controlled by the use of exclusion net. The aim of this work was to evaluate the losses produced by birds and the financial feasibility of the installation of exclusion net in an apple crop. Formulation and evaluation of projects was a technique applied to evaluate this investment, considering seven years of life project. The investment was $\$ 41,042$ / ha, and the incoming was $\$ 8,765$ / ha/year, so the repayment period was four years and IRR of $16.17 \%$, the ratio B / C of 1.23 . It was determined a production loss of $25 \%$ as breakeven point from which the investment is desirable. Investment is viable, particularly with high levels of damage.

Key words: Bird damage, Exclusion net; Apple crop.

1.- Cátedra de Sanidad Vegetal. Facultad de Ciencias Agrarias, Universidad Nacional del Litoral. Kreder 2805. (3080) Esperanza, provincia de Santa Fe. email: rrscotta@fca.unl.edu.ar 2.- Cátedras de Economía, Mercadeo Agroalimentario y Administración de Organizaciones. FCA (UNL). Manuscrito recibido el 12 de noviembre de 2013 y aceptado para su publicación el 17 de febrero de 2014. 